\title{
Collapse settlement of dump soils revealed by studies on soil samples of modelled lithology and lump-size distribution
}

\author{
Henryk WOŹNIAK ${ }^{1, *}$ \\ 1 AGH University of Science and Technology, Department of Hydrogeology and Engineering Geology, al. A. Mickiewicza \\ 30, 30-059 Kraków, Poland
}

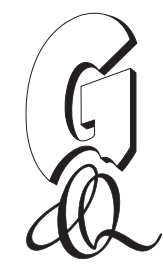

Woźniak, H., 2015. Collapse settlement of dump soils revealed by studies on soil samples of modelled lithology and lump-size distribution. Geological Quarterly, 59 (2): 391-399, doi: 10.7306/gq.1196

\begin{abstract}
The paper deals with the collapse settlement of dump soils i.e., made grounds composed of the overburden soils of mineral deposits, which were worked out with the open-pit method, transported and deposited as a dumped fill. The principal aim of the studies was the analysis of factors controlling the collapse settlement process, mostly the structural model of dump soil and external determinants: initial compaction, initial water content and history of its changes in time as well as the history of loading of studied soil before saturation. In order to reflect the natural structure of dump soils, experiments were carried out on samples of specially modelled lithology and structure. Hence, the samples represented three basic structural models of such soils: non-cohesive, cohesive and transitional, partly cohesive/partly non-cohesive. Attention was paid to diversified dynamics of collapse settlement, which results from two clearly different processes: rebuilding of soil structure and additional consolidation settlement. It was found that from the physical point of view the collapse settlement results from the release of elastic energy delivered to the sample by loading before inundation and accumulated at the contact surfaces of soil lumps.
\end{abstract}

Key words: dump soil, dumped fill, collapse settlement, collapse potential, double porosity.

\section{INTRODUCTION}

The collapse settlement is a process of volume reduction of a soil with the increasing water content at constant load. Several alternative terms were proposed in the literature: "hydrocompression" (Brandon et al., 1990), "hydrocompaction" or "hydroconsolidation" (Lawton et al., 1989), "collapse compression" (Charles, 1994), "additional settlement" (Dmitruk, 1963) and "settlement due to inundation". However, the term "collapse settlement" is most commonly used as it is observed in the field as significant, quickly increasing settlements of collapse character. Also the character of increasing water content may vary significantly - it can be inundation, permeation, saturation or soaking and, under laboratory conditions - wetting, flooding or sluicing.

The collapse settlement has already been recognized as a theoretical problem in early days of the development of modern soil mechanics. However, further progress in understanding of this problem was relatively slow and usually forced by growing demand for solutions of practical issues for the purposes of building industry in the areas covered by macroporous or arid soils. At present, the collapse settlement of natural soils (partic-

\footnotetext{
*E-mail: hwozniak@geol.agh.edu.pl

Received: January 27, 2014; accepted: July 07, 2014; first published online: October 10, 2014.
}

ularly the macroporous and arid ones, which are of crucial importance) has been quite well-recognized and adequately described (see e.g., Holtz and Hilf, 1961; Dudley, 1970; Barden et al., 1973; Mitchell, 1976; Hauss and Heibaum, 1990; Rybicki and Woźniak, 1994; Houston et al., 1997; Day, 1999; Alonso and Oldencop, 2000).

Until the 1960's, the importance of collapse settlement in engineered fills had been apparently underestimated or even depreciated due to an erroneous opinion popular among geotechnicians that thoroughly designed and properly compacted fills, commonly made of adequately selected materials, should not reveal any significant settlement. However, numerous failures and serious damages of earthworks (Terzaghi, 1960; Clayton, 1980; Justo and Saura, 1983; Leonards and Davidson, 1984; Brandon et al., 1990; Burford and Charles, 1991; Tadepalli and Fredlund, 1991; Goodwin et al., 1993; Booth, 1997 and many others) clearly demonstrated that collapse settlement is not limited to macroporous, silty soils. Analyses of failures led to an alternative concept of physical controls of the process and facilitated the implementation of changes in technology of dumping, which enabled the engineers to reduce unfavourable processes.

Another type of soil in which collapse settlement plays important role is the dump soil. Dumps are uncontrolled fills composed of overburden soils covering the mineral deposits. During the open-pit mining, the overburden is worked out, transported and deposited in overburden dump. The dump soils are a specific type of soils as: (1) their initial, natural structure is destroyed, (2) various soils are displaced and randomly mixed, and (3) soils are affected by various changes and transforma- 
tions caused by external factors. As a result, dump soils are lithologically diversified, highly porous and their structure and physical/mechanical properties are highly unstable.

These features are particularly evident for cohesive dump soils. Primarily, in the deposit these soils formed layers of cohesive materials, whereas after working out these became mixtures of randomly distributed lumps showing highly diversified shapes and dimensions. Different behaviour of such soils in comparison with the natural soils, particularly under load, gave rise to the definition of cohesive dump soil as the second-type fragmented soil different from fragmented soil which is the subject of interest of classic soil mechanics (Dmitruk, 1965). Feda (1998) and Mašin et al. (2005) introduced the term "double porosity soils" and distinguished the intragranular porosity $\left(n_{i}, e_{i}\right)$ within the undestructed lumps and intergranular (inter-lump) porosity $\left(n_{e}, e_{e}\right)$ between the lumps themselves. Both the porosities contribute to the total porosity $\left(n_{t}, e_{t}\right)$ given by the formulae:

$$
\begin{aligned}
& n_{t}=n_{i}\left(1-n_{e}\right)+n_{e} \\
& e_{t}=e_{e}\left(1+e_{i}\right)+e_{i}
\end{aligned}
$$

In comparison with relatively well-understood collapse settlement of natural soils and construction fills, as revealed by laboratory experiments, field observations and building industry practice, the knowledge of collapse settlement in dump soils is very limited. The problem was studied at the Building Research Establishment in Britain for the purpose of development of waste dumps left after hard coal open-pit mining. The results were published by Charles and Burford (1987) who analysed some failures in buildings founded on such waste dumps, and found excessive infiltration of meteoric waters as the reason, by Charles et al. (1993) who correlated the results of long-term measurements of dump settlement with the assessment of groundwater table reconstruction after closure of the mine and cessation of drainage, and by Hills and Denby (1996) who presented predictions of dump settlement caused by creeping and collapse settlement using the OBSett (Opencast Backfill Settlement Prediction Package) software.

Furthermore, the number of papers reporting on the results of laboratory studies is inadequate. Feda and Boháč (1997) and Feda (1998) presented the results of experiments run on modelled samples of dump soils. These samples were prepared from lumps of clays collected from the overburden of coal seams in southwestern Bohemia. An interesting and valuable paper was published by Blanchfield and Anderson (2001) who presented the results of large-scale laboratory experiments carried on samples of diversified lump composition prepared from overburden mudstones collected at the open pit mine in Pithouse near Sheffield.

Below are shown the results of studies which aimed: (1) to evaluate the importance of external factors for collapse settlement of dump soils and (2) to point out the differences in progress and scale of this process in dump soils, natural soils and compacted soils. In order to reflect the natural structure of a dump soil, samples of modelled lithology and structure were prepared. These samples represented three basic structural models of soils: cohesive, non-cohesive and intermediate, partly cohesive/partly non-cohesive. Samples were prepared from Quaternary sands and silty loams as well as from Neogene clays, all collected at the Bełchatów lignite open-pit (central Poland; Fig. 1). Modeling of lump composition of cohesive soils was run with hand fragmentation of monolith samples collected from dumps into 3 or 4 populations of irregular lumps of



Fig. 1. Location of the Bełchatów lignite open pit

diameters $5-10,10-15$ and $15-20$ or $15-25 \mathrm{~mm}$. These fractions were then thoroughly mixed in equal weight proportions. In order to consider the influence of moisture on the lump deformation process, samples of various moisture were collected. Sand used in the experiments was medium-grained, of water content $7-10 \%$. Similar procedure was applied to samples of partly non-cohesive/partly cohesive soils.

Experiments were run under uniaxial strain conditions with the Rowe hydraulic consolidation cells of $151 \mathrm{~mm}$ diameter and $40 \mathrm{~mm}$ height (Woźniak, 2001). Limited dimensions of the test chamber enabled to run experiments only for samples of reduced lump size. Obviously, such results do not reflect the true process with sufficient accuracy. If referred to the true conditions, the results should be corrected using a number of requirements coming out from the probability theory (Rozsypal, 1990). Unfortunately, the introduction of such corrections is difficult and, sometimes, even impossible. Woźniak (2009b) presented a method of extrapolation with the hyperbolic functions of settlement dependent on the average lump diameter obtained from tests of samples of successively increasing ranges of lump size.

\section{PHYSICAL CONTROLS}

Generally, there is an agreement between researchers concerning the external reasons of collapse settlement. The conditions necessary for generation of collapse settlement due to increased water content in made grounds (including natural and dump soils) were specified by Charles (1994) as:

- inadequate compaction of fills during their construction;

- undersaturation (i.e., below the critical degree of saturation $S_{r c}$ ) if, simultaneously, the fill was never fully saturated before;

- presence of load which can be very low but does not equal zero.

However, opinions become different when the explanation of internal factors is attempted. According to various hypotheses, the most commonly proposed reasons of collapse settlement are: (1) loss of cohesiveness and disturbance of microporosity, (2) inadequate consolidation of macroporous soils, (3) disintegration and dissolution by waters leading to 
damage of aggregates, (4) breaking of crystallisation bonds and (5) reduction of matrix suction. Such factors are typical of natural, particularly macroporous soils. In dump soils, in which at least local effects of the above-mentioned factors cannot be precluded, the principal reason for collapse settlement is total restructuring of the ground caused by weakening of bonds between the components of soil structure, not weakness of internal bonds within the lumps. Such restructuring is facilitated by relatively loose spatial arrangement of components, weak bonds between them (or even the lack of bonds) and the presence of large open spaces. Restructuring is particularly important in cohesive dump soils. When water content increases, plastic deformations appears in such soils and large open spaces between lumps are reduced, which results in significant settlement.

\section{PARAMETERS AND DETERMINATION METHODS}

The collapse settlement process under uniaxial strain conditions can be characterized by two parameters: collapse potential $C P$ and relative axial strain $\varepsilon$. Collapse potential describes susceptibility of soils to collapse settlement whereas axial strain expresses progressing increment of deformations with time, both before and after wettening.

Determination of collapse potential with field methods were not as widely applied as common field methods, such as: soundings, dilatometer tests and pressuremeter. These tests generally used in geotechnics cannot be applied because difficulties arise when one attempts to link the obtained parameters with those representing the collapse settlement. Simultaneously, unsatisfactory results were obtained from plate loading tests under inundation. In this case considerable errors appear caused by nonuniform inundation of the basement. Incomplete saturation by waters infiltrating from the surface occurred, despite uniform sprinkling.

Therefore, oedometer tests are regarded to be most credible. Among a variety of versions differing in loading-saturation sequences (see Jennings and Knight, 1957; Houston et al., 1988; Lawton et al., 1991), the single oedometer test was applied. In this method, after application of initial load $\sigma_{s e}$, which aims to cause compaction similar to that achieved by soil after dumping, the sample is subjected to further, progressive load up to a defined stress $\sigma_{i}$, and then saturated under this load until the water content balance is achieved (Fig. 2). Construction of a settlement-load curve after saturation requires tests of several samples, each saturated under different load and represented as a single point of the curve. The advantage of this method is the correcttion of errors that result from inhomogeneity of studied samples. This feature makes the single oedometer test particularly suitable for studies on dump soils.

Depending on recorded data, the value of collapse potential can be calculated using one of the following equivalent formulae (Reznik, 2000):

$$
\begin{gathered}
C P=\frac{h_{u s}-h_{s}}{h_{0}} \\
C P=\frac{\Delta h_{s}-\Delta h_{u s}}{h_{0}}=\varepsilon_{s}-\varepsilon_{u s} \\
C P=\frac{e_{0}-e_{s}}{1+e_{0}}-\frac{e_{0}-e_{u s}}{1+e_{0}}=\frac{e_{u s}-e_{s}}{1+e_{0}}
\end{gathered}
$$

Used symbols are explained in Figure 2.

\section{ANALYSIS OF FACTORS CONTROLLING THE COLLAPSE SETTLEMENT IN DUMP SOILS}

Collapse settlement is a function of many components, which can be divided into two groups. The first group embraces factors controlling the type of dump soil and its susceptibility to collapse settlement:

- structural model of the soil, i.e., quantity of lumps composed of cohesive soils and grains composed of non-cohesive soils together with their spatial arrangement;

- lump-size distribution of cohesive soils and grain-size distribution of non-cohesive soils;

- inter-lump and intergranular bonds (cementation, suction);

- lithology of source material;

- strength of source material and resistance against water action.

The second group includes the external factors:



Fig. 2. The single-oedometer test method

$h_{0}, h_{u s}, h_{s}$ - sample height (initial, before saturation, after saturation); $e_{0}, e_{u s}, e_{s}-$ void ratio (initial, before saturation, after saturation); $\varepsilon_{0}, \varepsilon_{u s}, \varepsilon_{s}-$ axial strain (initial, before saturation, after saturation); $\sigma_{s e}-$ initial load; $\sigma_{i}-$ load at saturation 


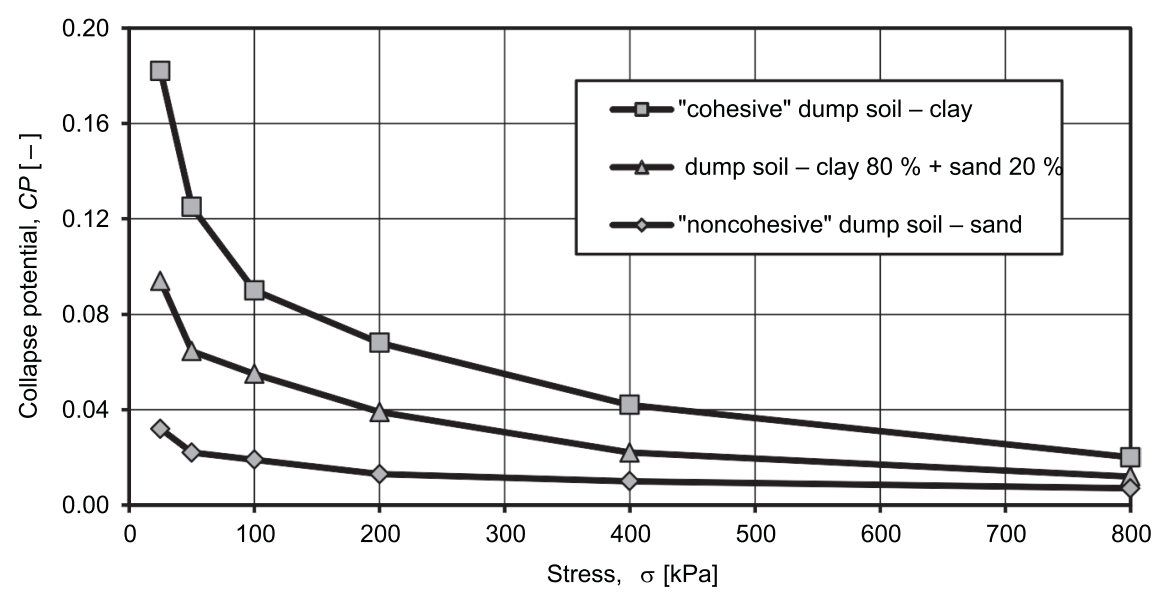

\begin{tabular}{|l|l|c|c|c|}
\hline Soil & $\begin{array}{l}\text { Range of lumps } \\
\text { dimension }\end{array}$ & $\begin{array}{l}w_{i} \\
{[\%]}\end{array}$ & $\begin{array}{l}w_{P} \\
{[\%]}\end{array}$ & $\begin{array}{l}w_{L} \\
{[\%]}\end{array}$ \\
\hline $\begin{array}{l}\text { clay } \\
\text { sand }\end{array}$ & $5-25 \mathrm{~mm}$ & 19.4 & 21.0 & 44.4 \\
\hline
\end{tabular}

Fig. 3. Influence of structural model of dump soils on the value of collapse potential

$w_{i}-$ natural (initial) water content; $w_{P}-$ plastic limit; $w_{L}-$ liquid limit

- initial compaction, i.e., compaction of soil before water saturation,

- initial water content and history of water content changes,

- initial load, stress state and stress history before water saturation.

\section{TYPE OF SOIL}

Among factors of the first group the most important is the structural model of dump soil. Its importance is well-illustrated by the results of tests carried out on three samples of Bełchatów material representing three principal structural models of dump soils: "non-cohesive", "partly cohesive/partly non-cohesive" and "cohesive" (Fig. 3).

The lowest values of collapse potential $C P$ occur in the "non-cohesive" model. However, for studied sand subjected to $25 \mathrm{kPa}$ load, the $C P$ value was 0.032 , which exceeds by $50 \%$ the boundary value $(C P=0.02)$ between soils of stable and unstable (collapse) structure. Small settlement increments due to inundation were observed even during compaction under $800 \mathrm{kPa}$ load.

The highest values of collapse settlement were observed in "cohesive" dump soils. The highly favourable factor is the loose, unstable lump structure, which is subjected to advanced restructuring caused by increasing water content and related soaking, and progressing plastic deformations. The CP potential for studied semisolid clay compacted under $25 \mathrm{kPa}$ load reached 0.182 , which is nine times over the boundary value for soils of stable structure (i.e. resistant to water action). The results of studies of other "cohesive" dump soils demonstrated that, in the extreme cases, the $C P$ value may reach even 0.28 . Dependence between $C P$ and strain for such soils is close to hyperbolic, which indicates that the collapse settlement of "cohesive" dump soils is a non-linear process of dynamics clearly decreasing with the increasing strain.

The presence of non-cohesive soils in the "partly cohesive/partly non-cohesive" model causes drastic decrease of

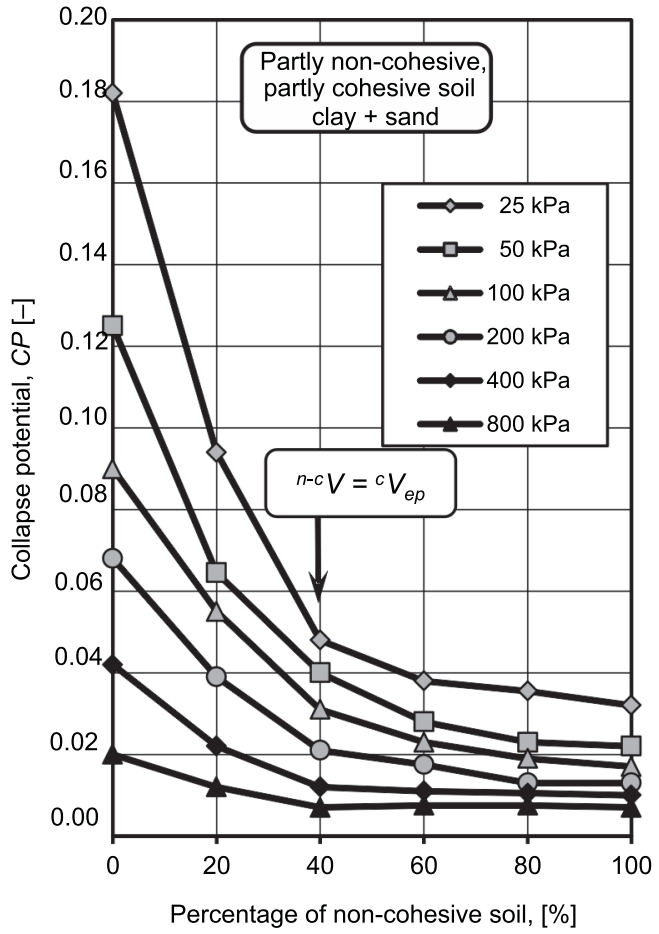

\begin{tabular}{|l|c|l|l|l|l|}
\hline Soil & $\begin{array}{l}\text { Range of lumps } \\
\text { dimension }\end{array}$ & $\begin{array}{l}n_{i} \\
{[\%]}\end{array}$ & $\begin{array}{l}w_{i} \\
{[\%]}\end{array}$ & $\begin{array}{l}W_{P} \\
{[\%]}\end{array}$ & $\begin{array}{l}w_{L} \\
{[\%]}\end{array}$ \\
\hline clay & $5-25 \mathrm{~mm}$ & 0.33 & 19.4 & 21.0 & 44.4 \\
sand & $0.04-2 \mathrm{~mm}$ & - & 7.8 & - & - \\
\hline
\end{tabular}

Fig. 4. Influence of the content of non-cohesive soil on collapse potential of "partly cohesive/partly non-cohesive" soil

${ }^{n-c} V$ - volume of non-cohesive soils; ${ }^{c} V_{e p}$ - volume of inter-lump pores in cohesive soils; $n_{i}$ - intragranular porosity; other explanations as in Figure 3 


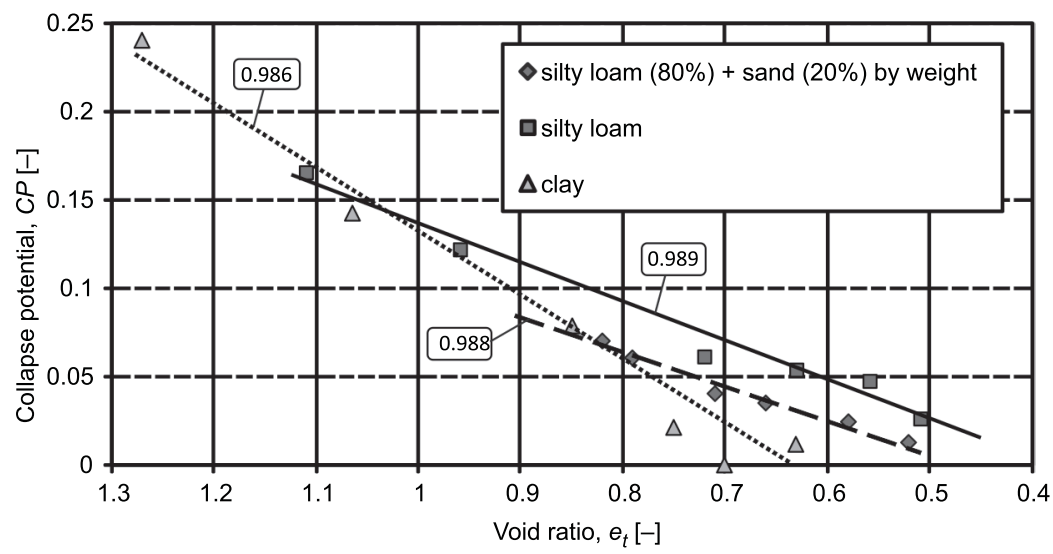

\begin{tabular}{|l|c|c|c|c|}
\hline Soil & $\begin{array}{l}\text { Range of lumps } \\
\text { dimension }\end{array}$ & $\begin{array}{l}W_{i} \\
{[\%]}\end{array}$ & $\begin{array}{l}W_{P} \\
{[\%]}\end{array}$ & $\begin{array}{l}w_{L} \\
{[\%]}\end{array}$ \\
\hline silty loam & $5-25 \mathrm{~mm}$ & 17.1 & 19.5 & 30.2 \\
clay & $5-25 \mathrm{~mm}$ & 20.8 & 23.4 & 43.7 \\
sand & $0.04-2 \mathrm{~mm}$ & 9.2 & - & - \\
\hline
\end{tabular}

Fig. 5. Collapse potential versus initial compaction in selected dump soils

collapse potential (Fig. 4) as a result of filling the open spaces between lumps of cohesive soil with the non-cohesive material. As the inter-lump porosity of uncompacted clay samples of given lump-size distribution varied from 37 to $41 \%$, a $20 \%$ admixture of sand results in approximately two-fold decrease in the possibility of further volume changes, which may appear due to reduction of inter-lump pores.

The importance of non-cohesive soils in the reduction of collapse potential $C P$ appears as a distinct drop in the slope of the curve of $C P$ versus content of non-cohesive soils in Figure 4. At the point at which the volume ${ }^{n-c} V$ equals the volume of inter-lump pores in cohesive soils ${ }^{c} V_{e p .}$ a $40 \%$ drop is observed. A similar drop is observed at the point at which the content of non-cohesive soils is equal to the volume of inter-lump pores in cohesive soils was found during compressibility studies of other dump soils representing this model (Woźniak, 2009a, b).

\section{COMPACTION}

The principal reason for collapse settlement process is inadequate compaction, i.e. the presence of structural pattern which may be subjected to further compaction under favourable water content. Hence, any initial compaction, i.e., compaction before inundation, decreases the existing collapse potential and decisively influences the ongoing reduction of the collapse settlement process.

In contrast to the distinctly curvilinear dependence of collapse potential on strain, the collapse potential-porosity relation indicates very good linear correlation (correlation coefficients close to 1, Fig. 5).

The presented plots demonstrate that properly high initial compaction may reduce or even eliminate the collapse settlement. Based upon studies on compacted clayey sands, Lawton et al. (1989) proposed the concept that a critical value of the relative compaction exists, above which the soils does not reveal collapse settlement due to increasing water content. Furthermore, these authors found that the critical value of the degree of compaction is not constant for given soil but increases with the increasing load from the overburden. This concept was confirmed by Charles (1994) who found that the essential condition for such state of compaction is the reduction of the volume of pores filled with the air below the critical value (usually about $5 \%$ ). Per analogiam it can be concluded that, also for dump soils, there exists a compaction value for which the increasing water content does not result in further volume changes.

\section{WATER CONTENT}

Initial water content of a soil is an important factor influencing the compaction under given load from the overburden. It is particularly valid for "cohesive" dump soils in which the increasing water content facilitates deformation of lumps and reduction of inter-lump porosity, which results in increasing compaction. It can be concluded that initial water content before inundation influences the collapse potential in the same degree as it influences soil compaction.

Figure 6 displays results of studies on three samples of lumpy silty clay of water contents $8.8 ; 17.1$ and $25.2 \%$, respectively, subjected to $100 \mathrm{kPa}$ load. Before saturation, deformation values for all three samples varied from $3.3 \%$ in sample of $8.8 \%$ water content to $15.2 \%$ for sample of $25.2 \%$ water content. However, after saturation the deformation values were remarkably similar. The author's studies (Woźniak et al.,1997; Woźniak, 2009b, c) indicated that such behavior of soils occurred as well at different loads and that, independently of the load, the increase of initial water content significantly affects decreasing collapse potential and decreasing collapse settlement values.

The results of studies published by many authors indicate that full saturation of pore spaces with water is not necessary for full settlement. Based on the studies on natural soils, El-Ehwany and Houston (1990) reported that only 50\% saturation results in $85 \%$ of total collapse settlement and at $65-70 \%$ saturation, even $95 \%$ of total collapse settlement can be 

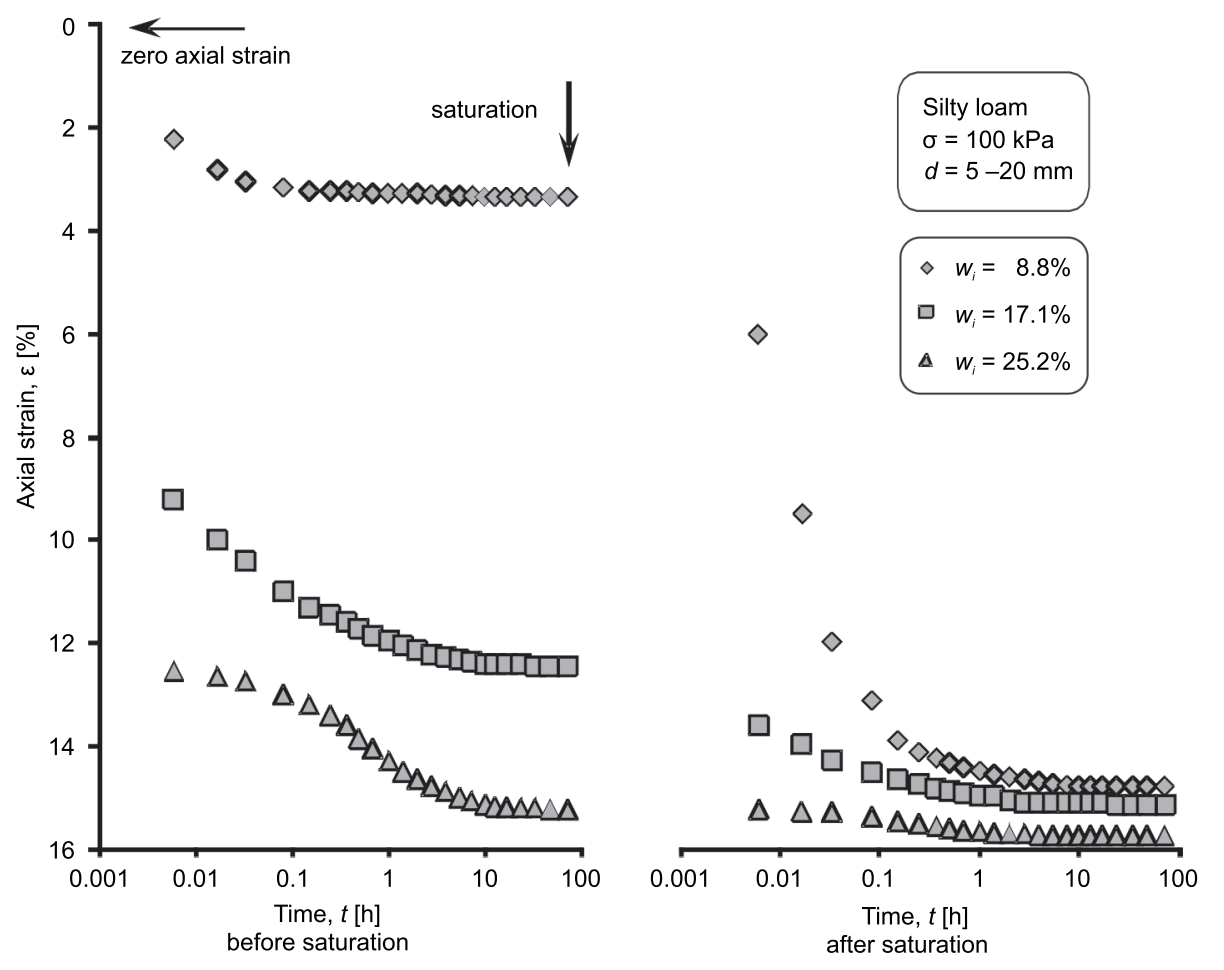

Fig. 6. Influence of initial water content of "cohesive" soil on its strain before and after water saturation

achieved. Similar values were published by Charles (1994) for compacted soils, whereas Blanchfield and Anderson (2001), who studied coarse-grained dump soils in large-dimension apparatus (diameter $775 \mathrm{~mm}$ ), obtained a curve which demonstrates that full settlement of these soils took place under 80-85\% saturation. However, Lawton et al. (1992) proposed that the critical saturation at which collapse settlement can be neglected depends on the overburden pressure.

Based upon the obtained results, the above-mentioned authors state that saturation at the level of $90 \%$ obtained in laboratory experiments is sufficient for collapse settlement studies, and procedures leading to the full saturation are unnecessary. El-Ehwany and Houston (1990) demonstrated that, under field conditions, the lower saturation is achieved for the same soils in comparison with laboratory experiments. Hence, the settlement values obtained from laboratory experiments can be regarded as overestimated in relation to the true values.

\section{LOAD}

The presence of high load before water saturation is regarded as one of the factors necessary for the appearance of collapse settlement. However, the results of author's studies indicated that dump soils settle even under self-weight due to water saturation when being only tens of centimetres thick. Therefore, the appearance of collapse settlement at the practical lack of any load should be regarded as one of the factors which make collapse settlement in dump soils different than in natural or compacted soils.

Although the load is not a necessary factor for the appearance of collapse settlement in dump soils, it is still the factor which controls the development of collapse settlement process. The loading of soil before inundation results in increasing compaction and reduction of high porosity. In such a case, the activation of compaction due to water inflow is more gentle and its values are lower.
An abrupt decrease of collapse potential with the load is accompanied by decrease in the share of collapse settlement in total settlement of a soil (Fig. 7). In studied clay samples at $50 \mathrm{kPa}$ load, the collapse settlement constitutes over $50 \%$ of total settlement. At $100 \mathrm{kPa}$ load, collapse settlement is reduced to $29 \%$ of total settlement, and it disappears under $800 \mathrm{kPa}$. It indicates that, under natural conditions, the values of collapse settlement can be highly diversified within the volume of given dump.

The increase of water content may result in two different processes: volume decrease due to collapse settlement and volume increase due to swelling. In natural soils and compacted fills, which reveal expansion, the criterion diagnostic for both processes is the load - under lower loads the swelling occurs, whereas under higher loads the collapse settlement appears. The value of boundary load is not constant. Apart from the type of soil, it depends mostly on compaction and water content under which the soil was compacted (Brandon et al., 1990) and on suction pressure (Vilar, 1994). For dump soils, the load criterion does not apply. Very high porosity of dump soils causes that large settlements occur even under insignificant loads that neutralize any possible swelling. However, measurable values of swelling may appear in overconsolidated dump soils. Rzeszut (1989) studied swelled samples composed of lumps of dump clays (5-15 mm in diameter and water content of 10.8\%) and found swelling after compaction under $200 \mathrm{kPa}$ load.

\section{DYNAMICS OF COLLAPSE SETTLEMENT PROCESS}

The shapes of deformation-after-saturation versus time plots (Fig. 8) demonstrate that the development of collapse settlement in time is highly diversified. Three main phases of this process can be distinguished: I - the phase of instantaneous or almost instantaneous deformations, II - the transitional phase 


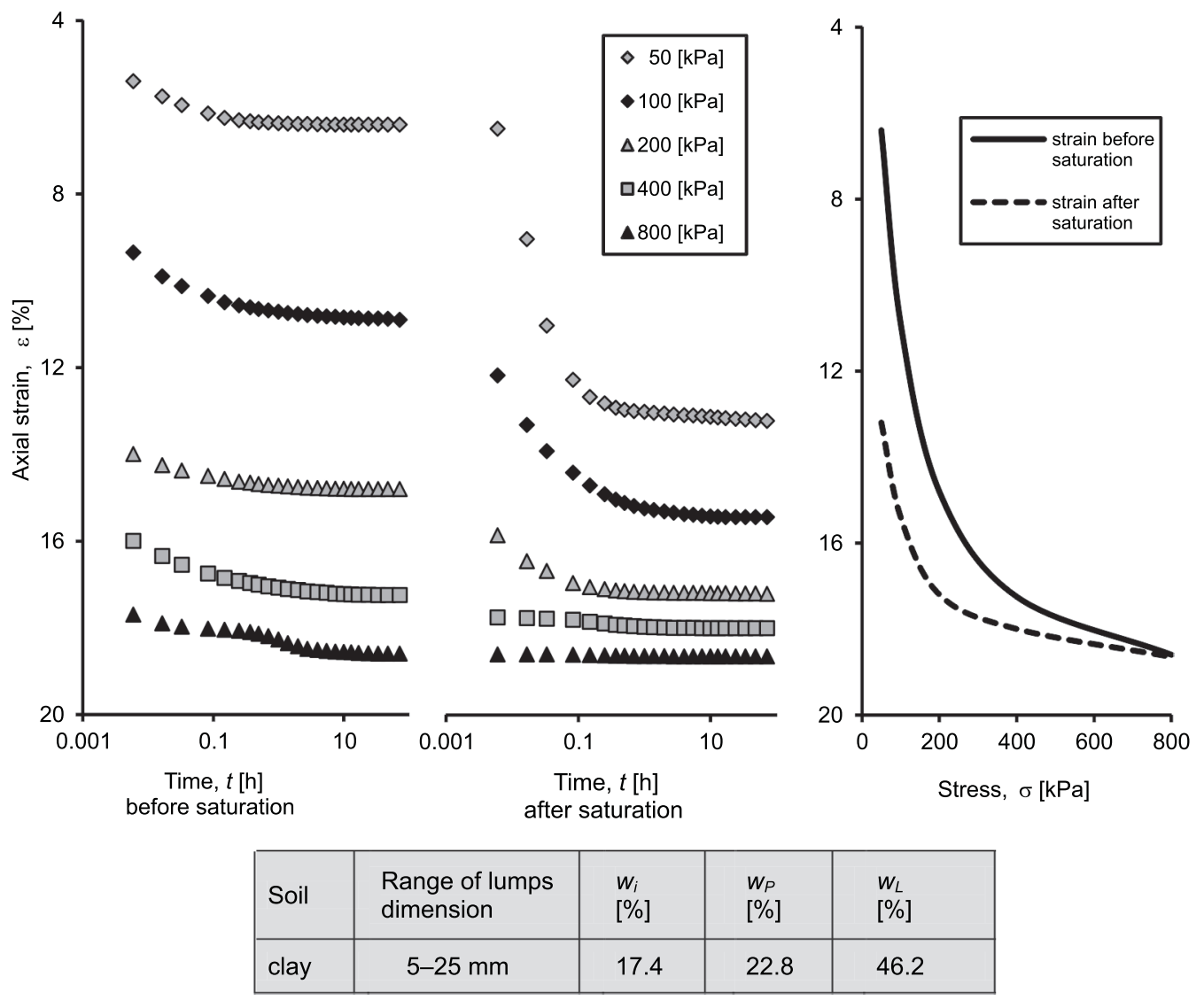

Fig. 7. Influence of initial load on collapse potential

Explanations as in Figure 3
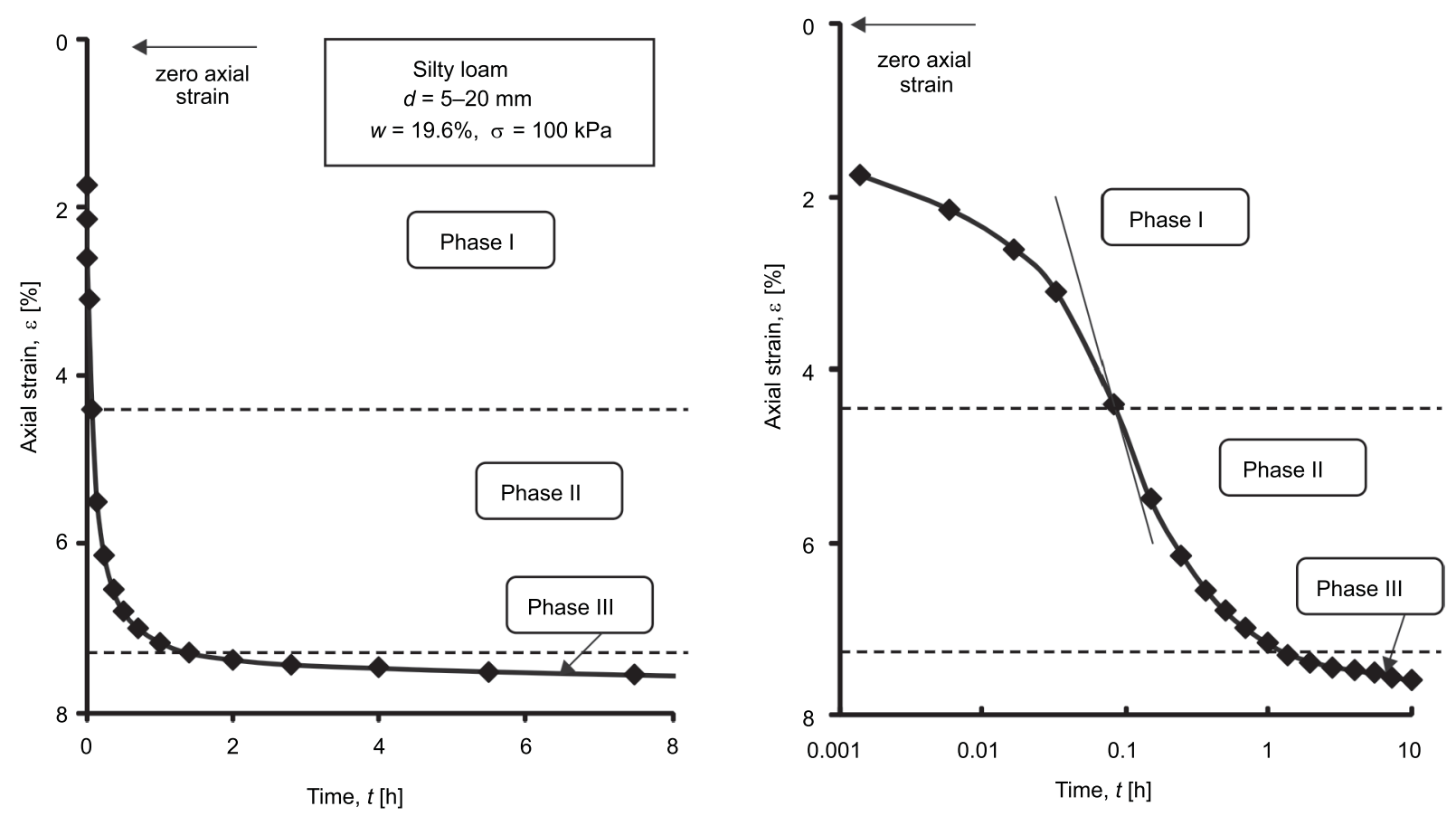

Fig. 8. Deformation phases in collapse settlement process 
and III - the phase of long-term deformations. Distinguishing of distinct phases of diversified increment rates of deformations points out that the collapse settlement includes two separate processes: restructuring and consolidation. In order to distinguish clearly between the results of both processes, it is proposed (after terminology introduced by Dmitruk, 1963) to use the name "structural settlement" for the settlement process related to remodelling of soil structure and "additional consolidation settlement" for the settlement which occurs after soil restructuring.

The structural settlement develops mainly in phase I, it is rapid (almost abrupt) and is particularly characteristic for "cohesive" dump soils of typical lump structure. Infiltration of water into the pore spaces of such soils results in destruction of structural bonds, soaking, plastic deformation of lumps, and reduction of pore size. Hence, the lump structure collapses and significant settlement appears. An additional but important effect accompanying the structural settlement is the systematically progressing stabilization of soil structure.

The additional consolidation settlement occurs mostly in phases II and III, under conditions of a new structure stabilized during phase I. In contrast to the structural settlement, this process is slow and long-lasting, particularly in phase III where it has the character of secondary (rheologic) consolidation of linear progress dependent of the logarithm of time.

The described dynamics of collapse settlement process based upon the results of laboratory experiments does not correspond directly to the dynamics of process under natural conditions of waste dump. Particularly, in specific parts of the dump volume all three phases may occur simultaneously and their results may interfere. Hence, under natural conditions, the collapse settlement can be considered only holistically and its development in time will depend on the rate of infiltration and rate of reaction of soil for flooding.

\section{SUMMARY AND CONCLUSIONS}

The collapse settlement is an important componenet of total settlement of dump soils. In many cases the settlement values are comparable or even exceed those resulting from self-weight settlements. Both the prediction and the estimation of settlement values play important roles in solutions of practical geotechnical problems related to the construction and development of waste dumps. The knowledge of the influence of various factors on the values and character of collapse settlement is inevitable for:

- evaluation of slope stability of dumps, both for the whole dump and for its parts;

- sensible dimensioning of dumps for more correct determination of volume and for correct solutions of safety problems;

- evaluation of settlement diversity as a criterion of possible usage of dump surface as a base of landfills;
- making correct decisions on type of recultivation and development of post-mining lands.

The size of collapse settlements of dump soils is controlled by many factors, which can be divided into two groups. The first group deals with the type and properties of soils, and includes a structural model of given soil, its lithology, resistance to soaking and water action, and the presence of inter-lump and inter-granular bonds. The second group includes the external factors: initial compaction, initial water content and its history, stress history reflecting the loads to which the soil was subjected before saturation.

The values of collapse settlement of dump soils are highly diversified. In "non-cohesive" model, which reveals the lowest susceptibility for collapse settlement due to increasing water content, the collpase potential values $C P$ only rarely exceed 0.02 , which is regarded as a boundary value between soils of stable and unstable structure under water action. The highest collapse settlements occur in soils of "cohesive" model where the extreme $C P$ values may exceed even several times the boundary value. The collapse potentials of "partly cohesive/partly non-cohesive" soils reveal strong dependence on the content of non-cohesive material. The non-cohesive soil plays the role of filling medium for inter-lump pores, and strongly reduces the collapse potential, particularly if its contents are lower than inter-lump porosity. Clearly curvilinear character of collapse potential versus load plot indicates that the collapse settlement is a non-linear process of highly diversified dynamics.

The important role of initial water content and load, as external factors in collapse settlement, forces the deeper analysis of these processes which develop within the dump soils under increasing water content. These processes and their results can be explained in terms of the analysis of energy transformation which was transferred to the sample by loading before flooding. Part of this energy was used for plastic strains, i.e. for mutual displacements of lumps and their permanent deformations, whereas the remaining energy was transferred into elastic strains at the contacts of lumps and within lumps. When water is introduced, the existing energy equilibrium is disturbed. The released elastic strain energy is used for further plastic strains, which results in large and abrupt collapse settlements. Thus, from the physical point of view, the collapse settlement is caused by the release of elastic energy accumulated at the contact surfaces of soil lumps. Consequently, the lower water content and the higher load result in higher energy accumulation in elastic strains and in a higher degree of restructuring of the soil under inundation. Such interpretation explains the importance of two factors mentioned above: initial water content and load, and demonstrates their mutual equivalence.

Acknowledgments. The author is grateful to Prof. P. Dobak, an anonymous reviewer and Prof. T.M. Peryt for the revision and valuable critical comments that significantly improved the manuscript. 


\section{REFERENCES}

Alonso, E.E., Oldencop, L.A., 2000. Fundamentals of rockfill collapse. Unsaturated soils for Asia In: Proc. of the Asian Conf. on Unsaturated Soils, Singapore: 3-13. Balkema, Rotterdam.

Barden, L., McGown, A., Collins, K., 1973. The collapse mechanism in partly saturated soil. Engineering Geology, 7: 49-60.

Blanchfield, R., Anderson, W.F., 2001. Settlement of opencast coal mine backfill in large scale laboratory tests. GREEN 3. The exploitation of natural resources and the consequences: 447-456. Thomas Telford, London.

Booth, A.R., 1977. Collapse settlement in compacted soils. CSIR Res. Report 324, Council for Scientific and Industrial Research, Pretoria, South Africa.

Brandon, T.L., Duncan, J.M., Gardner, W.S., 1990. Hydrocompression settlement of deep fills. Journal of Geotechnical Engineering, 116: 1536-1548.

Burford, D., Charles, J.A., 1991. Long-term performance of houses built on opencast ironstone mining backfill at Corby, 1975-1990. Round Movements and Structures. Proc. 4th Int. Conf. Held in Cardiff: 54-67. Pentech Press, London.

Charles, J.A., 1994. Collapse compression of fills on inundation. In: Geotechnical Engineering: Emerging Trends in Design and Practice (ed. K.R. Saxena).: 353-375. Balkema, Rotterdam.

Charles, J.A., Burford, D., 1987. Settlement and groundwater in opencast mining backfills. Proc. 9th Eur. Conf. Soil Mechanics and Found. Eng., Dublin, vol. 1: 289-292. Balkema, Rotterdam.

Charles, J.A., Burford, D., Hughes, D.B., 1993. Settlement of opencast coal mining backfill at Horsley 1973-1992. Proc. of the conf. "Engineered fills '93”, Newcastle upon Tyne: 429-439.

Clayton, C.R.I., 1980. The collapse of compacted chalk fill. Proc. Int. Conf. Compaction, 1: 119-124, Paris.

Day, R.W., 1999. Geotechnical and Foundation Engineering. Design and Construction. McGrown-Hill, New York.

Dmitruk, S., 1963. Rozważania nad cechami lessu właściwego (in Polish). Archiwum Hydrotechniki, 10: 79-92.

Dmitruk, S., 1965. Zadania mechaniki gruntów w wymiarowaniu zwałowisk (in Polish). Zeszyty Naukowe Politechniki Wrocławskiej, 116: 3-117.

Dudley, J.H., 1970. Review of collapsing soils. Journal Soil Mechanics and Foundations Division, ASCE, 96: 925-947.

El-Ehwany, M., Houston, L.S., 1990. Settlement and moisture movement in collapsible soils. Journal of Geotechnical Engineering, 116: 1521-1535.

Feda, J., 1998. Fragmentary clay - a difficult waste material. Engineering Geology, 51: 77-88.

Feda, J., Boháč, J., 1997. Collapsible behaviour of granulated clay. Proc. 14th Int. Conf. on Soil Mech. and Found. Eng., Hamburg: 287-290. Balkema, Rotterdam.

Goodwin, A.K., Holden, J.M.W., Kirkpatrick, S.W., 1993. Performance of an engineered fill at Lounge opencast coal site. Proc. of the Conf. "Engineered fill '93", Newcastle upon Tyne: 413-428.

Hauss, K.D., Heibaum, M.H., 1990. Settlement due to saturation. 6th Inter. IAEG Congress: 3075-3081. Balkema.

Hills, C.W.W., Denby, B., 1996. The prediction of opencast backfill settlement. Proc. Inst. Civ. Engrs. Geotech. Eng., 119: 167-176.

Holtz, W.G., Hilf, J.W., 1961. Settlement of soil foundations due to saturation. Proc. $5^{\text {th }}$ Int. Conf. Soil Mech. and Found. Engrg., Paris, 1: 673-679. Dunod, Paris.

Houston, S.L., Houston, W.N., Spadola, D.J., 1988. Prediction of fill collapse of soils due to wetting. Journal of Geotechnical Engineering, 114: 40-58.

Houston, W.N., Houston, S.L., Walsh, K.D., 1997. Arid soil problem. Proc. 14th Int. Conf. on Soil Mech. and Found. Engrg., Hamburg: 119-122. Balkema, Rotterdam.
Jennings, J.E., Knight, K., 1957. The additional settlement of foundations due to a collapse of structure of sandy subsoils on wetting. Proc. 4th Conf. Soil Mech. and Found. Eng., London, 1: 316-319. Butterworths, London.

Justo, J.L., Saura, J., 1983. Three-dimensional analysis of Infiemillo dam during construction and filling of the reservoir. International Journal for Numerical and Analytical Methods in Geomechanics, 7: 225-243.

Lawton, E.C., Fragaszy, R.J., Hardcastle, J.H., 1989. Collapse of compacted clayey sand. Journal of Geotechnical Engineering, ASCE, 115: 1252-1267.

Lawton, E.C., Fragaszy, R.J., Hardcastle, J.H., 1991. Stress ratio effects on collapse of compacted clayey sand. Journal of Geotechnical Engineering, 117: 714-730.

Lawton, E.C., Fragaszy, R.J., Hetherington, M.D., 1992. Review of wetting-induced collapse in compacted soil. Journal of Geotechnical Engineering, 118: 1376-1394.

Leonards, G.A., Davidson, L.W., 1984. Reconsideration of failure initiating mechanisms for Teton Dam. Proc. Int. Conf. Case Histories in Geotechnical Engineering, St. Luis, 3: 1103-1113. University of Missouri-Rolla, Missouri.

Mašin, D., Herbstová, V., Boháč, J., 2005. Properties of double porosity clayfills and suitable costitutive models. 16 ICSMGE, Osaka: 827-830.

Mitchell, J.K., 1976. Fabric, structure and property relationships. In: Fundamentals of soil behavior: 222-252. John Wiley \& Sons, New York.

Reznik, Y.M., 2000. Engineering approach to interpretation of oedometer tests performed on collapsible soils. Engineering Geology, 57: 205-213.

Rozsypal, A., 1990. Determination of mechanical properties of rockfill on model samples with reduced grain size distribution curve. 6th Inter IAEG Congress: 3125-3130. Balkema, Rotterdam.

Rybicki, S., Woźniak, H., 1994. Shear strength of dump soils with references to water saturation. Proc. 7th Int. Congress IAEG, Lisboa: 2847-2851.

Rzeszut, P., 1989. Osiadanie gruntów zwałowanych (in Polish). M.Sc. thesis, AGH.

Tadepalli, R., Fredlund, D.G., 1991. The collapse behaviour of a compacted soil during inundation. Canadian Geotechnical Journal, 28: 477-488.

Terzaghi, K., 1960. Discussion on Salt Springs and Lower Bear River Dams. Transactions of the American Society of Civil Engineers, 125: 139-159.

Vilar, O.M., 1994. Collapse of compacted clay under controlled suction. 7th Inter. IAEG Congress: 501-506. Balkema, Rotterdam.

Woźniak, H., 2001. Zastosowanie konsolidometru hydraulicznego Rowe'a do badania odkształceń objętościowych gruntów nasypowych w wyniku zawodnienia (in Polish). Kwartalnik AGH, Geologia, 27: 513-525.

Woźniak, H., 2009a. Influence of water content on compressibility of cohesive dump soils - results of studies on samples of modeled lump size distribution. Geologija, 51: 53-58.

Woźniak, H., 2009b. The settlement of dump soils - data from modeling (in Polish with English summary). IGSMiE PAN Kraków.

Woźniak, H., 2009c. Właściwości deformacyjne i filtracyjne zwałowanych gruntów spoistych z wybranych kopalń odkrywkowych w aspekcie ich budowlanego wykorzystania (in Polish). Wyd. FALL, Kraków.

Woźniak H., Herzig J., Rzeszut P., 1997. Collapse subsidence in dump soils of unstable structure. 2nd Int. Green Symp. on Geotechnics and the Environment, Theme: Contaminated and Derelict Land., Kraków: 184-191. 